\title{
Entrepreneurship and identity politics: an analysis from the perspective of figuration sociology and critical social psychology
}

\author{
ANGelo BRigato ÉStheR ${ }^{1}$ \\ ${ }^{1}$ Universidade Federal de Juiz de Fora (UFJF) / Faculdade de Administração e CiÊnCias Contábeis, Juiz de Fora - MG, BRAZIL
}

\begin{abstract}
The article discusses the concept of identity articulating elements of the critical perspective in social psychology, especially from the syntagm identity-metamorphosis-emancipation developed by Antonio Ciampa, as well as the concept of 'identity politics.' In parallel, the study reflects on the contributions of Norbert Elias connected to the conceptions of Ciampa. Entrepreneuship is understood as a fundamental structuring concept of identity, as a presupposed, idealized identity. The study does not takes a position contrary to entrepreneurship, but discusses the prevailing meanings that have been attributed to entrepreneurship, whose construction constitutes an ideological and mythicized identity politics..
\end{abstract}

Keywords: Identity. Identity politics. Entrepreneurship.

A política de identidade do empreendedorismo: uma análise na perspectiva da sociologia fguracional e da psicologia social crítica

\section{Resumo}

Este artigo discute a identidade articulando elementos da perspectiva crítica em psicologia social, especialmente a partir do sintagma identidade-metamorfose-emancipação desenvolvido por Antônio Ciampa, bem como o conceito de políticas de identidade. Paralelamente, as contribuições de Norbert Elias são utilizadas para a reflexão, articulando-se às concepções de Ciampa. Para tanto, toma-se o empreendedorismo como conceito estruturador fundamental da identidade, enquanto identidade pressuposta idealizada. De todo modo, não se trata de assumir uma posição contrária ao empreendedorismo ou ao fato de alguém empreender alguma atividade. Trata-se, porém, de discutir o significado predominante que tem sido atribuído ao empreendedorismo, cuja construção constitui uma política de identidade de caráter ideológico e fetichizado.

Palavras-chave: Identidade. Política de identidade. Empreendedorismo.

La política de identidad del espíritu emprendedor: un análisis desde la perspectiva de la sociología figuracional y de la psicología social crítica

\section{Resumen}

Este ensayo analiza la identidad articulando elementos desde una perspectiva crítica en psicología social, especialmente a partir del sintagma identidad-metamorfosis-emancipación elaborado por Antonio Ciampa, así como el concepto de políticas de identidad. Paralelamente, se utilizan los aportes de Norbert Elias para la reflexión, para la reflexión, articulándolos a las concepciones de Ciampa. Para ello, se toma el espíritu empresarial como un concepto fundamental de la estructuración de la identidad como identidad presupuesta idealizada. En cualquier caso, no se trata de asumir una posición contraria a la iniciativa empresarial o al hecho de que alguien emprenda alguna actividad. Se trata, sin embargo, de discutir el significado predominante que se ha atribuido a la iniciativa empresarial, cuya construcción constituye una política de identidad de carácter ideológico y fetichizado.

Palabras clave: Identidad. Política de identidad. Espíritu emprendedor. 


\section{INTRODUCTION}

Entrepreneurship is a subject that is gaining more space and adherents every day in terms of its significance, even though this does not always happen in a critical or conscious manner. This may imply the diffusion of an ideology to the extent that entrepreneurship is presented as a panacea for all economic and social woes in a noncritical manner, constituting what Chauí (2007) calls a competent discourse. Moreover, to the extent that it gains ideological dimensions, it also contributes to the establishment of the politics of identity, providing an identity reference for individuals, organizations and institutions through a group of desirable attributes and characteristics associated with an imaginary social setting within which individual and collective success is measured and calibrated by the parameters associated with this concept.

This process constitutes a stereotype, or in other words, a group of beliefs related to individual characteristics related to personality, behavior (DESCHAMPS and MOLINER, 2009) and forms of action, generally shared by a given group. Sometimes, stereotypes can become a positive reference - constituting an established group, for example (ELIAS and SCOTSON, 2000), or a negative reference, constituting a group of outsiders (ELIAS and SCOTSON, 2000; BECKER, 2008) or a stigmatized group (GOFFMAN, 2008).

The concept of identity, initially associated with an individual, has been applied to organizations and institutions in a reified transposition, that makes the organization "equal" to the individual, as if they were separate and independent $a$ priori, as in the critique of Elias (1994a) in regard to this dominant conception of the individual and society (individual/collective). If the individual-society (I-S) separation is something dominant - as is explained later in this article - from this perspective identity will be understood in the same way, or in other words, it will presuppose a separation between individual identity and collective identity. This is what Norbert Elias and Antônio Ciampa seek to avoid.

"Identity as a concept is fully as elusive as is everyone's sense of his or her own personal identity. But whatever else it may be, identity is connected with the fateful appraisals made of oneself by oneself and by others." (STRAUSS, 1969, p. 9). Thus, this article discusses identity, articulating elements of critical perspectives from social psychology, especially the identity-metamorphosis-emancipation syntagma developed by Antônio Ciampa, as well as the concept of the politics of identity. In parallel, the contributions of Norbert Elias are used for reflection, articulating the concepts of Ciampa. To do this, entrepreneurship is taken to be a fundamental structuring concept of identity, a presupposed idealized identity, even though we point out that in a strict sense identity cannot be summarized or reduced to a single defining criterion or parameter (SEN, 2006), but we can show one "side" of it, so to speak. However, this side has assumed significant weight and character, given its ideological construction.

In any event, this does not assume a position contrary to entrepreneurship or the idea of someone undertaking some activity. It is rather discussing the predominant significance that has been attributed to entrepreneurship, whose construction constitutes the politics of identity with implications for human actions.

\section{Theoretical perspectives and their approximation}

Psychology as an area of specialization is relatively recent in this country, with the profession of psychology becoming regulated in the 1960s. Its orientation was fundamentally positivist and its role was restricted to some extent to contributing to the modernization of the country which implied reconciling individuals to liberal assumptions. In this sense, the theoretical perspective, the ideological, assumed that men are equal and, at the extreme, responsible for their successes and failures, denying Brazilian reality in terms of its social and cultural aspects, inherited from colonial times (LANE, 1994). Thus, there would be no explicit recognition of social inequalities, maintaining and perpetuating relationships of dominance. In the field of social psychology, the application of concepts and techniques from the United States was taken to be a fundamental reference and studies sought to find universal laws, which would lead to the reproduction of hegemonic capitalist ideology (POKER, 2014). According to Lima, Ciampa and Almeida (2009, p. 225), the author assumes a materialist position, showing "that there is no way to separate reality from theory, and theory from research, as does positivism, which always regards the place of scientific theory as being neutral."

On one hand, there is the pragmatic American tradition and its objective of harmonizing group relations, minimizing negative conflicts and attempting to make groups productive, and on the other hand we have the European phenomenological tradition which searches for total models. However, the critiques on all sides ended up demonstrating the limits of the dominant 
perspective of the ideological and reproducing nature of an idealized man whose behavior should be controlled based on a universal ideal and the positivist paradigm (LANE, 1994).

Thus, this critical position led a group of researchers in Brazil to consider man to be a historical and social product. In the words of Silvia Lane (1994, p. 12), "man is culture, is history." In this sense,

[...] if psychology describes what is observed or focuses on the individual as the cause and effect of individuality, it will have a conservative, statist - ideological - effect no matter what practices result from it. If man is not seen as a product and a producer, not just through his personal history, but from the point of view of the history of society, Psychology will just be reproducing the conditions necessary to impede the emergence of contradictions and social transformation (LANE, 1994, p. 15).

In this reorientation, the role of Lane and Codo (1994) proved fundamental to the path which others followed, especially the works of Antônio Ciampa in regard to identity ${ }^{1}$.

To Antônio Ciampa, identity is a fundamentally political issue. With the book The Story of Severino and the History of Severina (CIAMPA, 1987), the author inaugurated a perspective which broke with the dominant positivist perspective in this country, and therefore any essentialist or naturalist conception of identity. On the contrary, to Ciampa (1994, p. 64), "we are our actions, we make ourselves through practice." In addition, to the author, individuals are presented as the bearers of multiple roles, establishing an "intricate network of representations that permeates all relationships, where each identity reflects another identity, which eliminates the possibility of establishing an original foundation for each of them" (CIAMPA, 1994, p. 67). Identity assumes various forms, but the form "personality" is the one that best expresses it empirically.

Therefore, human existence is not guaranteed beforehand, neither is natural change. On the contrary, man is not limited to his future in function of a preestablished goal, nor is he free from the historical conditions in which he lives, as if his future were absolutely undetermined. On the contrary, as Habermas (1983) affirms, adults are capable of constructing new identities in situations of conflict, for example. Therefore, the question of identity refers to a political project. Man is not purely subjectivity and consciousness; he also is not just one thing, just objectivity. This duality should be overcome by praxis, engaging himself in

[...] projects of human coexistence which make possible a sense of history as the realization of a future made with others [...] projects that are not predefined by a model of society and man, that all are affected by totally (and identically), but rather projects that can present, converge or compete in the real transformation of our conditions of existence, in such a way that the true human being comes to exist (CIAMPA, 1994, p. 73-74).

Also, according to Ciampa (1994, p. 74-75), "identity is movement, it is the development of the concrete. Identity is metamorphosis." The author's goal is a conception of identity that leads to human emancipation or fragments of emancipation. Thus, the author uses the identity-metamorphosis-emancipation syntagma as a resource to demonstrate the inseparable articulation of these dimensions.

In this theoretical itinerary - associated with the historical itinerary-social psychology breaks with positivism and adopts the presuppositions of historical materialism as the basis of the development of its theory of identity. Evidently this change of direction does not occur in a natural or essential manner; on the contrary, it is the fruit of a determined vision of the world, according to which emancipation is a possible condition, determined socio-historically, of the evolution of human society over centuries (and not any more the evolution of the species which determines human transformations during humanity's prehistory). Once understood as a metamorphosis, identity develops in a sequence of forms of recognition, and "this recognition, when it is absent or occurs in an inhuman fashion, individuals experience as being imprisoned in the same routine, and the fetish of a character which impedes the reification of the emancipatory meaning of identity" (LIMA, 2010, p. 140).

\footnotetext{
${ }^{1}$ The work of Silvia Lane is considered to be of great relevance to the field of Psychology, and she is considered by some to be a type of founder of the so-called "São Paulo School" (cf. CARVALHO, 2014). The book that she organized with Wanderley Codo is viewed as a landmark in this area (LANE and CODO, 1994).
} 
Considering liberal capitalist diktats that impose their ideology and resulting forms of desired action, critical social psychology contributes to so-called critical theory, especially Jürgen Habermas.

Based on Habermas (1983), Ciampa (2006) distinguishes the "I identity" from the "role identity." Sometimes, role identities (attributed and reproduced collectively) suggest the existence of an identity a priori or an identity essence. From this comes the expression "conventional identity." On the other hand, "post-conventional" identity, from Habermas's perspective, is that which is defined by the process and not by a priori content. In this way, role identity has to do with a collective dimension associated with a fundamental discussion, pointed out by Ciampa (2006): the politics of identity and political identity.

The politics of identity seek to normalize or homogenize collectivity, leading its members to share forms of significance which are considered relevant to the meaning of the activity of each one. Collective identity is considered to be a group of forms of significance which are shared by many people and interfere with determining significance in the personal formation of each one. ${ }^{2}$ The most conservative groups will be the greatest defenders of conventional profiles. The more one group or more exercises hegemony in terms of the politics of identity, this power will determine or influence the way in which each person recognizes himself or herself and is recognized (CIAMPA, 2006).

At the same time, all identity is political - in its individual dimension - to the extent that individuals seek to define themselves in a particular way, even if they are articulating a socially established role. From this we derive the concept of character. Each individual is an actor and an author in constructing his or her character more or less creatively (CIAMPA, 1987). In other words, identity in its analytic dimension, is taken to be a constitutive element of the forms of contemporary sociability (CASTRO and LISBÃO, 2017).

It would be impossible for an individual to live without personalities. However, the passive interiorization of an intense predication of oneself (or in other words, the assimilation of attributed identities, including through the politics of identity) ends up making identity concrete, almost prohibiting the subject from "living for himself," generating what the author terms myth or fetish identity (CIAMPA, 1987).

At the same time, to Ciampa (2006), the notion of personality always contains a dose of transgression, failing to obey the conventional.

Identity makes politics concrete; it gives form to an ideology. Together identities constitute society, at the same time that they are constituted one by one by it. The issue of identity, thus... is above all a social issue, a political issue (CIAMPA, 1987, p. 127).

In a strict sense,

[...] individuals are not just inoffensive receptacles who incorporate predications and embody them in daily life, and they also propose new characters, it is they who determine them; they are not just citizens and members of the community, they also react to this community and transform its reactions (LIMA and CIAMPA, 2012, p. 21).

As the authors state, individuals configure their personal identities, entangled in social relationships, in the middle of a life story and project, mediated by the language of various processes and institutions.

In sum, we can affirm schematically the theoretical aspects of this proposition of critical social psychology (LIMA and CIAMPA, 2012, p. 15):
a) The constitution of the subject occurs through his or her insertion in a network of interactions mediated by language;
b) Human identity as a metamorphosis is a permanent process that occurs through socialization;
c) Individuation which occurs through socialization, depends on what is associated with the growth of personal autonomy;

\footnotetext{
2Even though the expression "politics of identity" tends to be identified as "a way of understanding collective and individual actions in a manner which does not marginalize the life experiences of the oppressed or excluded people of a society due to the fact that it seeks to recognize cultural and social identities which are different from the dominant ones" (GUARESCHI, 2000), in this article we have adopted a broader conception, similar to that offered by Ciampa (2006). In the case discussed here, we understand entrepreneurship as the politics of identity that seeks to homogenize according to a group of shared forms of significance based on a model of society and the individual from the point of view of the dominant class economically. In other words, it is not just conceived of as the politics of resistance, but also as the politics of domination.
} 
d) The concretization of an individual's intended identity, as an expression of autonomy, presupposes its recognition by other individuals.

This is how Ciampa, within the tradition of social psychology, seeks to investigate how the individual and society relate, assuming, however, that there is a dialectic relationship between them. Since the beginning of his work, Ciampa has assumed that "understanding identity is understanding the individual-society relationship, because this is what makes it possible to perceive social issues, for example, systemic inequalities and barriers, as well as understand the forms that individual resistance takes as well as subjects' searches for emancipation" (SOUZA and GONÇALVES, 2017, p. 7).

In this aspect, he comes close to the perspective of Norbert Elias, for whom the individual/society (I-S) dichotomy is a fallacy and a mistake, an "intellectual aberration" (ELIAS, 2008, p. 140). From his point of view, these instances can be even considered distinct, but never separate and autonomous (ELIAS, 1994a). In this sense, the author shows that the concept of this division has led, inclusively, to a separation between fields of study: one which studies the individual, psychology; and the other which studies society, sociology (ELIAS, 2008).

According to Norbert Elias, society is a figuration of interdependent individuals, or in other words, society does not exist without individuals. In separating one instance from another, and considering society as something that is independent of individuals, he reinforces the idea that society is made up of structures which are outside of us, and that individuals are surrounded by society and separated by an invisible barrier. Due to their interdependence and the way in which the actions and experiences of individuals penetrate each other, they form a configuration or a type of a relatively autonomous order, or in other words, no one is capable of determining this figuration or direction as if they commanded this process (ELIAS, 2008) ${ }^{3}$.

Even though identity goes through transformations independent of ideology, at least through the sense of physical aging, for example, we consider that we are not born human, but rather we can be humanized, as Elias (1994a) also assumes. Thus, we can verify that there is a founding metamorphosis which constitutes the humanization process and what occurs under the social conditions prevailing at the time of birth. Thus, man is, at the same time, his past (which presents itself at this moment as life history) and his future (which presents itself as life plans). And this is why we can state that we are always our present, which depends on our past and our future. To do this, Ciampa asks himself (together with Jean-Paul Sartre): "what should I do about what they've done to me?"

In this way, identity presents itself as a permanent process of metamorphosis, whose sense of permanent struggle for emancipation is represented by the identity-metamorphosis-emancipation syntagma, or in other words, you cannot talk about any of these three elements without talking about the other two. On the other hand, sometimes identity presents itself as a "non-metamorphosis." In practice, what occurs is that man ends up replenishing that which has been done before, which in the author's terms constitutes the same routine with identity being the answer, when we see another other whom we also are (CIAMPA, 1987, 2004).

Identity as metamorphosis is possible to the extent that we assume a dialectic I-S relationship, as does Ciampa and Elias. Ciampa's idea of emancipation is in consonance with this presupposition, because how could this be possible without a relationship with the "other?" In other words, what Elias wants to avoid - Ciampa as well - is the danger of believing that an anti-social individual exists, as an agent who exists only for himself, and the danger of postulating the existence of a system or a whole, or in other words, a society which exists beyond individual beings and beyond all individuals (ELIAS, 2006) ${ }^{4}$. To the author, objective reality is the reification of a concept, which tends to reinforce the idea that society is constituted by structures which are outside of us, and that individuals are surrounded by society and separated by an invisible barrier. According to this point of view, in the civilization process (ELIAS, 1994b) there is a correspondence between social structure and the structure of personality (or psychological structures) of the individual at a given stage of development within society. This process could be characterized in general as a process of change, repression and the control of behavior, instincts and desires. Even though people have individual freedom of movement, there is also a species of invisible order that cannot be directly perceived by the senses. Each person belongs to a given place, has a function, property or a specific job. It is not always possible to leave where you are, leave your conditions.

\footnotetext{
${ }^{3}$ The author uses the terms figuration and configuration interchangeably, as synonyms. Over time he has come to prefer the term figuration ${ }^{4} \mathrm{Cf}$. Chapter1: Fundamental concepts.
} 
The author also notes, "this invisible order into which individual purposes are constantly being introduced, does not owe its origin simply to a summation of wills, a common decision by many individual people. It does not occur based on the free decisions of many, a social contract, and still less is it based on referenda or elections" (ELIAS, 1991, p. 15). In truth, referenda and elections only occur when permanent institutions of social control act together with a very specific structure of social functions. However, at the same time, social structures do not exist outside of individuals. In other words, individuals live through their relationships and they assume specific figurations, but have their own social structures.

Norbert Elias admits that identity has to do as much with differences as it does with similarities between individuals in a society. The former the author terms the I-identity and the latter he terms the we-identity. To discuss this, we need to take into account society's stage of development. To the author, for example, current society favors l-identity as the more visible dimension, given the value attributed to individualism in capitalistic society, even though at certain times we-identity has taken precedence over I-identity. Elias (1991, p. 157) explains this relationship in the following manner:

The republican Roman state of antiquity is a classical example of a stage of development at which the sense of belonging to family, tribe and state, i.e. the we-identity of the individual person, carried far more weight in the we-I balance than today. Thus, we-identity was hardly separable from the image the language-shaping classes had of the individual person. The notion of a groupless individual, of a person as he or she would be if divested of all we- reference, as he or she would appear if the isolated person were rated so highly that all we-relations, such as family, tribe or state, were deemed relatively unimportant, such a notion was still largely below the horizon in the social praxis of the ancient world.

Elias explains that each person, even though he or she is singular and different from all of the others, has a habitus, or a social composition, that is shared with the other members of a society. From our point of view, the individual and collective dimensions are interwoven in the understanding of this dialectic. The individual within society presents what the author calls the "social structure of personality," or in other words, individuals find themselves in given "stages and patterns of individual self-regulation" - as discussed in his book about the civilizing process ${ }^{5}$ - associated with a social habitus. This habitus constitutes, in the view of the author,

[...] the soil from which grow the personal characteristics through which an individual differs from other members of his society. In this way something grows out of the common language which the individual shares with others and which is certainly a component of the social habitus - a more or less individual style, what might be called an unmistakable individual handwriting that grows out of the social script (ELIAS, 1991, p. 182).

In other words, individuals carry with them the habitus of a group that is then individualized to a greater or lesser extent. In accordance with his conception, "we see how indissoluble a person's existence as an individual being is from his or her existence as a social being" (ELIAS, 1991, p. 187). The I-we identity is a constituent part of a person's social habitus, which leaves individualization open. Identity is an answer to the question "who am I?" as a social being and an individual. It is important to clarify that in our I-S dialect "there is no I-identity without we-identity. Only the weighting of the I-we balance, the pattern of the I-we relation, are variable" (ELIAS, 1991, p. 184).

It may be perceived that even though he never refers to Elias, Ciampa's perspective is totally compatible with that author. Elias even refers to emancipation, sometimes expressing it through the concept of autonomy. To this author, an individual human can have relative autonomy in relation to given figurations, but in relation to figurations in general, when there are many, only in extreme cases (i.e. insanity). Figurations that form here and now can have relative autonomy in relation to given individuals, but never in relation to individuals in general. It can be put in another way:

An individual human can have freedom of action which makes it possible to leave a given figuration, and enter another, whether and to the extent that this is possible depends, in fact, on the particular characteristics of the figuration in question. The same people can also form part of various different

\footnotetext{
${ }^{5}$ In the words of Cintya Greive Veiga (2017, p. 174), Norbert Elias "analyzes the values involved in the passage from monarchical states to nation states, when the bourgeois classes began to defend human rights and the natural progress of humanity as an argument for the elimination of absolutist oppression." In sum, the civilizing process is characterized by alterations in the "behavior of people through the development of the need for calming impulses and, therefore, the rationalization of attitudes, as well as the capacity for foresight and self-control, in the same proportion that physical violence was monopolized by the State, through regulation in the legal field, penalties and punishment in which people no longer arbitrated their own conflicts" (VEIGA, 2009, p. 85).
} 
figurations [...]. Inversely, various individual humans can form similar figurations with certain variations (families, bureaucracies, cities, and countries) (ELIAS, 2006, p. 27).

In the conception of Elias (2008), it has become evident that power exercises itself in a relational way, and is not being conceived any more as a type of substance. To the author, considering that configurations are mutable, there is a floating and elastic balance of power - what he calls the "power gradient" - and this fluctuating balance is a structural characteristic of the flow of each configuration. Depending on the complexity of the configuration - a country or a city for example - it sometimes becomes difficult to perceive various axes of interdependence in a society, whose configuration is measured by power relationships, codes of behavior and feelings which are guaranteed by the constraints to which subjects and groups are exposed. Elias (1997) lists four types:

1. Constraints imposed on people by their natural characteristics, such as the imperatives of hunger or thirst, sexual impulses, as well as those associated with aging, death, hatred, love and others of this kind.

2. Constraints due to dependence on natural circumstances especially those imposed by the need to look for food or protection against the climate and weather, for example.

3. Social constraints, or in other words, those imposed mutually by people in their social life, are due to inevitable relationships of interdependence. The author mentions "external constraints", emphasizing that they are "constraints by other people". In a broad dimension, it includes paying taxes, but it can involve just two people.

4. Self-constraints, or in other words, self-control. "Reason" and "conscience" are considered mechanisms of selfcontrol. It differs from the first type of constraint because in this form there exists the potential for self-constraint, or in other words, this mechanism needs to be activated or realized by experience or learning and depends on the society within which this person grows up, and changes over the length of the human development process.

Elias makes it clear, that due to the civilizing process, the mechanism of self-control has become stronger than external constraints, becoming more uniform and broader. According to the author, it is common that self-control is developed in relation to the establishment, especially in terms of relations with peers in societies with very unequal proportions of power. According to Elias (1997), those who have power are those who occupy the highest positions of the hierarchy, who do not need to contain themselves when dealing with their inferiors on the social scale, and therefore "let themselves go."

The author makes it clear that to understand the experience of the individual (and groups), it is not enough to have a historical narrative, one needs to construct a "verifiable theoretical model of the configuration that a person [...] forms in his or her interdependence with other social figures of the time" (ELIAS, 1995, p. 18-19), and also understand a society's stage of development at a given moment in time. One has to understand the "social structure model of the time, especially when there are differences in power. It is only within the structure of such a model that one can discern what a person [...], involved in this society," is capable of doing or not in terms of individuals (ELIAS, 1995, p. 19).

\section{Entrepreneurship and the entrepreneur: emergence and the politics of identity}

The subject of entrepreneurship and the entrepreneur has received growing attention and space, especially since this country promoted the opening of the economy in the beginning of the 1990s, which implied the end of market reserves and the adoption of a free market and competition along with the vectors and paradigms of capitalist development. This scenario was reinforced within the purview of the State in its structure and management based on the State reform promoted by the administration of Fernando Henrique Cardoso, within the precepts of what is generically termed New Public Management, with its resulting privatization of public services and organizations and the gradual implementation of private management methods in the public management environment. The public sector, therefore, came to be seen as dysfunctional and incompetent, given its bureaucratic rationality, which needed to be forcibly substituted by business rationality, which became known as managerialism ${ }^{6}$. Where privatization did not occur, the implementation of business

\footnotetext{
${ }^{6}$ New Public Management (NPM) is theoretically based on neoliberal thinking and the theory of public choice. Its implementation occurred, among other elements, due to the crisis of the Welfare State and the rise of managerialism, with it being necessary to reestablish the entrepreneurial culture of the Victoria era, which resulted in a form of public management which takes the business ideal as a reference for the entire public sector (PAULA, 2005).
} 
logic was implemented gradually in all sectors, including public universities (ÉSTHER, 2017), and within the "spirit" of so-called entrepreneurial universities (ÉSTHER, 2016).

With the removal of protectionist policies and mechanisms from the government market in general, companies began to face foreign competition, which required them to adopt new production methods and management, consolidated and favored by productive restructuring. Since then, private and public organizations have adopted policies and practices of rationalization, which include among other things, hierarchical restructuring and downsizing. Within this context, the intensive use of production technology, associated with management technologies, led to a significant reduction in personnel, and also implied new postures for employees and managers. At the same time, restructuring led to layoffs of large groups of employees, who overnight had to find alternatives to formal employment to survive. This combined with the difficulty of youths seeking their first job; it is within this context that entrepreneurship and the figure of the entrepreneur emerged and gained force.

In terms of the State reform, it was accused of having created the inflated and faulty structure of social security, with employees who were equally inflated and incompetent, in addition to presenting outdated technology and many functions and activities that were not deemed competitive, and this thus ushered in the privatizations. Within this context, with widespread unemployment, looking for work was not a very viable alternative for many individuals. At the same time, being to some extent "used to" little competition and state protectionism in various fields, national companies had great difficulty in staying competitive. In the business field, micro and small companies began to emerge as an alternative to unemployment. With this wave, various state companies and organizations promoted voluntary resignations paying severance packages that exceeded legal requirements for those interested in resigning.

However, this situation just reinforced the statistics for micro and small companies that went out of business before one, two or three years of existence. Thus, based on these findings, a variety of actions and initiatives were established to promote entrepreneurship, more to prepare and instrumentalize those who opened small businesses. Banks opened lines of credit, governments created stimuluses, and various courses and training in business management, including MBAs extending even to secondary education with the goal of disseminating "entrepreneurial culture" in Brazil7. In the field of Administration, the literature on entrepreneurship is abundant, and often consists of true self-help manuals and promises of guaranteed success.

With the rationalization process, favored by more flexible labor legislation within the State's reform, the precariousness of work became evident in the first years of its implementation, and this has been proven statistically and is still felt today. This process led to the formation of a new class, the "precariat" class, being a mixture of precariousness and the proletariat. Even though it is not a very simple and precise definition, it seems evident that "precariousness also implies a lack of a secure work-based identity" (STANDING, 2011, p. 9). This is the same conclusion that Sennett (1998, p. 31) reaches in analyzing the transformations in capitalism and society, affirming that

[...] What's peculiar about uncertainty today is that it exists without any looming historical disaster; instead it is woven into the everyday practices of a vigorous capitalism. Instability is meant to be normal, Schumpeter's entrepreneur served up as an ideal Everyman. Perhaps the corroding of character is an inevitable consequence.

Perhaps, in other words, the corroding of identity due to the corrosion of what have been current references.

Currently, the "entrepreneurial culture" has permeated organizations and companies, reinforced by the media and business, which do not tire of arguing the virtues and possibilities of entrepreneurship as a panacea to the economic problems of employment and work. It appears that society has experienced a significant change in its structure and social habitus. Even though we cannot affirm that this process has been consolidated, it appears evident that the force of this idea is growing,

\footnotetext{
${ }^{7}$ The Brazilian senate is discussing the insertion of entrepreneurship as an interdisciplinary theme in schools. According to the senate's website, Bill $n$. 772 of 2015 alters Law n. 9394 of December 20, 1996 which establishes the guidelines and bases for national education, that mandate that curriculums in primary and secondary education include entrepreneurship as an interdisciplinary theme. It also includes an orientation towards work and entrepreneurship as a guideline for the curricular content of basic education, and also establishing the stimulus of entrepreneurship and innovation as a goal for higher education, emphasizing the connection between technical and scientific knowledge and the world of work and production (BRASIL, 2015).
} 
affecting almost all human activity, at least in terms of discourse. Economically, this habitus refers to neoliberalism, in which entrepreneurship is the key to the success of this model, because it imposes an innovative dimension at the same time that it attributes a central role to the individual on a behavioral level, whose implications which will be analyzed later.

But what, after all, does entrepreneurship mean and why are its discourse and narrative so forceful? It is usual to attribute the use of the term entrepreneurship to Jean Baptiste Say, even though it was made popular by Joseph Schumpeter through his idea of creative destruction, through which the new substitutes the old, offering renewal through individual initiative and the entrepreneurial spirit, leading to business innovation. However, in terms of the concept, it was developed in the field of modern management especially with the works of Peter Drucker during the 1980s (FILION, 1999; CAMPOS and SOEIRO, 2016). Since then, some perspectives relating to entrepreneurship have been presented, including attempts to explain entrepreneurial behavior or spirit based on various categories, including psychological characteristics and even personality traits or innate characteristics of the individual (CUNNINGHAM and LISCHERON, 1991), forging an image of practically a "superman".

Great figures have been used as "inspirations" and references to illustrate the force and power of the entrepreneur. One of the emblematic icons of this force is certainly Steve Jobs, who is also mentioned by Campos and Soeiro (2016). To the authors, his image has been constructed to define and identify the myth of Steve Jobs, or in other words, just some of his characteristics are used to denote his ability and the extent of his success, understood as economic and financial success. Other characteristics and situations like, for example, his practices of moral harassment and lawsuits are never cited, even when they seem to be compensated for by the "positive" traits of his image.

The emphasis on "positive" traits is a strategy mentioned by Elias, in relation to an "established group" and an "outsider group" in a small English town. In his own words, Elias and Scotson (1994a, p. xix),

[...] an established group tends to attribute to its outsider group as a whole the "bad" characteristics of that group's "worst" section - of its anomic minority. In contrast, the self-image of the established group tends to be modelled on its exemplary, most "nomic" or norm-setting section, on the minority of its "best" members.

This argument can be observed - even though they do not refer to it or Elias - when Campos and Soeiro (2016) point out that, while Steve Jobs is idolized and made into a myth as a prototype of an entrepreneur, Tim Berners Lee, the creator of the internet who did not patent it, is almost never remembered, even though he was responsible for an incalculable contribution to the development of information and communication technologies. This is why it has to do with the understanding of the entrepreneurial discourse of "its ideological production level as a legitimizing narrative of a given order of social life, supported by its own symbolism and iconography" (CAMPOS and SOEIRO, 2016, p. 24).

The entrepreneurial narrative seeks to give meaning to individual and collection actions. Associated with a group of practices and institutions that reinforce this narrative of entrepreneurship, it ends up turning into a type of politics of identity, as explained before. It seeks to serve as a reference for the construction of identities aligned with a given ideology, offering patterns of behavior and action that define people. All of this is processed and reproduced in various spheres and instances of socialization, constructing and reconstructing the habitus in its various layers and modifying various social figurations. This process can be understood, at least in part, as a social dynamic component of stigmatization (ELIAS and SCOTSON, 2000), or in other words, those who do not "fit in" to this habitus tend to be excluded. However, the entrepreneurial discourse becomes more perverse to the extent that it attributes success as well as failure to the individual, hiding and camouflaging any sociohistoric references the politics of social life.

As Campos and Soeiro (2016, p. 39) point out,

[...] entrepreneurship offers a semiotic scenario to interpret economic events at the same time as helping construct these events and their economic contexts. The necessity of this imagination, strong as it is natural and remote, is nothing new if we take into consideration that all economic regimes depend on devices of moral legitimation which give meaning to the transformations that are taking place. The effect of this is that the consent of these people to a given system is produced through their adherence to these narratives and the culture that produces them. Within a context that is removed from the critical 
theory of capitalism, one of the fields in which the work of constructing global meaning for ongoing transformations is precisely management in transforming the official narrative of new capitalism. It was from this field that entrepreneurship was diffused as an ideology.

With transformations occurring on the ideological plane as well as the material, institutions have also been transforming themselves, losing their character as the providers of meaning and identity for individuals. To Ciampa (1998, p. 97),

[...] on the level of society, the task for institutions consists in accumulating meanings and making them available to individuals, both for individual actions as well as one's entire conduct in life. Perturbations on this individual level appear as crises of orientation, alienation, and psychopathologies, in which the autonomy of a person is diminished, harming the development of personal identity as a subject capable of interaction. This is not referring to simple adaptation, as Habermas remembers [...], but rather the ability of the subject to continue to develop through successive re-adaptations without losing the feeling of his or her own temporal continuity.

In this sense, the critique of Sennett (2006) is interesting when compared to the configuration that he calls "new capitalism" as opposed to the "old capitalism". If before bureaucracies were considered instruments of domination in the Weberian sense - the famous metaphor of the iron cage - its downfall brings more freedom to modern society, according to the defenders of the new capitalism. However, in these terms, "changes do not liberate people" (SENNETT, 2006, p. 21). In other words, they do not facilitate their emancipation.

If Elias is correct when he affirms that it is common in societies with great inequality in terms of power to see self-control on the part of the establishment - or self-restraint - the ideology of entrepreneurship has been capable of creating an imaginary social scenario in which individuals identify with it, reinforcing the typical behavior of an entrepreneur - in which Steve Jobs is a emblematic mythic figure or a prototype of an entrepreneur - the ideal of identity as Ciampa's metamorphosis-emancipation seems to become more and more distant. As pointed out by Campos and Soeiro (2016, p. 34), figures such as Steve Jobs or Oprah are portrayed with almost messianic characteristics, ready to be followed by people, representing "the capture of meaning, which legitimates and naturalizes an image of dissonance in relation to reality."

In addition to all of this, the ideal entrepreneur practically removes the collective dimension from social life, operating with the almost complete distancing of the individual from society, reinforcing the image of separate and distinct entities. Moreover, removing the collective nature of work, the worker's perspective as a class in an economic and socially unequal system fades, attributing to the individual a statute - totally artificial - of the "owner" of his or her work effort, or even more the "owner" of his or her destiny. It also removes any understanding and responsibility governments and states have for public policy, because everything will be resolved through individual initiative. Finally, it magically makes the relationship between capital and work disappear, because everything is boiled down to individuals in a world in which there are only autonomous businessmen.

From the point of view of identity, the individual becomes an entrepreneur - his or her identity - only through effort and merit, independent of one's relationship with the "other," as illustrated in Figure 1. According to Campos and Soeiro (2016, p. 47), the promotion of the so-called entrepreneurial spirit as a way of being ends up constituting a "process of the inculcation of these deeper transformations of identity, through an attempt to adjust the subjectivity of the principles of maximizing profit, competition and individual initiative which regards the market as sovereign." In practice, the entrepreneurial narrative has constructed in parallel the image of the entrepreneur as a prototype of an idealized individual, deserving of social recognition, and the image of those who are the opposite, meaning that they do not deserve success because they don't put in the required effort and for this reason do not receive due recognition. Also, it can even be affirmed that a type of establishment-outsider relationship is being constructed, as conceived by Elias (1994a, p. xxxiv-xxxv):

The social stigma that its members attach to the outsiders group transforms itself in the imagination into a material stigma - it is reified. It appears as something objective, something implanted upon the outsiders by nature or the gods. In this way the stigmatizing group is exculpated from any blame: it is not we, such a fantasy implies, who have put a stigma on these people, but the powers that made the world - they have placed signs on these people to mark them as inferior or bad people. 
The defense of entrepreneurship - understood now as ideology - constitutes the defense of an excluding perspective because, it is certain that the social world is not made up of only entrepreneurs - even though this is the discourse of the ideological plan which has been widely publicized. As Amartya Sen (2006, p. 3) puts it, the "adversity of exclusion can be made to go hand in hand with the gifts of inclusion".

In other words, the entrepreneurial identity configures itself as an identity-inculcation-domination or identity-myth and not the identity-metamorphosis-emancipation perspective that is so dear to Ciampa, which presupposes a conscious, critical, and reflective individual capable of action. In the I-we balance of identity of Elias (1994a), the individual aspect of identity has gained more and more weight, perhaps coming close to overshadowing the existence of the we-identity. From this comes its ideological force. From this comes the conception of the identity-myth to the extent that the use of a symbolic system (language) ends up favoring an image that is ready to be appropriated and assimilated by individuals (CAMPOS and SOEIRO, 2016). While the politics of identity provides a prototype - such as Steve Jobs or Oprah, for example - it intends that the individual, empirically and materially, should assume a fetish-like identity to use the expression of Ciampa (1987).

\section{Figure 1}

\section{Atomistic Vision of an Entrepreneur}

\section{There's only one explanation for being desperate in a crisis.}

Yes, only one. If you are desperate about it, it's very likely that you suffer from this malady which is rapidly spreading through the Brazilian population. In fact, I have my doubts as to whether this malady has spread among Brazilians due to periods of economic stability or whether they have always suffered from this affliction.

Before revealing the only explanation for being desperate in a crisis, I will talk a little bit about it. It is not necessary to enter into many details about this subject, because you know that it began a while ago and has been responsible for the downfall of many people and businesses. The fundamental question at the moment is not discussing the causes or circumstances of this period of turbulence, but rather to know how to react in the face of this crisis.

I have received news that is not at all encouraging from the best specialists in the country, which I will announce even knowing how painful it will be to hear it. The more optimistic ones believe that during the second half of 2016 things will begin to improve, and the more pessimistic ones believe that things will only begin to turn around in 2017.

This means that even if there is a margin of error in the optimistic as well as the pessimistic projections, in both analyses the crisis will last until at least July 2016. I am writing this article in February. I have just left a meeting of business leaders who told me that since December 2015 this crisis has been ugly. And we still have March, April, May and June ahead of us (at least).

I see businessmen and professionals being laid off, professionals who are afraid of being laid off, salesmen, to name a few, complaining about this turbulent juncture in the market. People who complain about the economic situation in Brazil are the same ones who are desperate about the crisis. If you are one of those who has become desperate, know that there's only one explanation for this: complacency.

I do not know how you are reacting to the crisis, however, if you are afraid of it, it is because you haven't prepared yourself to face it. Did you know that the crisis would arrive? What attitude did you take in the face of this information? What will you do as the crisis continues? What will you do when it ends? Your answers to each of these questions indicate your preparation to prosper despite this crisis.

Brazil has gone through periods of economic stability such as the implementation of the Real Plan, which brought large profits to the same businessmen who today are being laid off, the professionals who are afraid of being laid off, and the salesmen who are complaining today. And you, have you prepared yourself to face this crisis?

The best time to plan changes is not when danger knocks on your door. On the contrary, it is when things are in order that changes are necessary. During unstable periods, anxiety increases and decisions need to be made immediately. You need time and tranquility to make the best decisions about your future or the future of your company. And this you can only do during times of stability.

Thus, even though before you didn't know about the crisis, for better or for worse, today you know the reality of the economic situation in Brazil. What attitude are you going to take in the face of this information? Are you going to continue complaining about the government, banks, customers and companies, or are you going to take responsibility for your own results?

Source: Muniz (2016). 


\section{FINAL CONSIDERATIONS}

At this point, it is clear that the reflections presented here do not represent an absolute position against someone undertaking an activity. On the contrary, people undertake ventures all the time. The question is the significance that has been attributed to this activity, and above all, why. The question could be put in another way: who has an interest in this significance? If it is the dominant class, which intends to maintain its system of domination, the ideological construction of this significance makes sense in terms of the politics of identity.

Here the politics of identity have been considered in a broad sense, or in other words, how one seeks to normalize a collective group. It is ideological to the extent that it naturalizes its shared significance, removing all of its historical, political and social character, seeking to construct and maintain an apparatus for its production and reproduction.

The model of man that results is expressed through an identity-myth or fetish, which therefore assumes a universal and natural character, independent of everything. In this sense, the idealized expectation is that each individual will assume this character as an actor, but never as an author, which is not compatible with the idealized prototype. This theoretically incorporates the myth of the individual in various layers of the social habitus.

In reducing identity to the entrepreneurial identity, so to speak - given that the diffusion of entrepreneurship as ideology presupposes it to be a "way of being," as an assumed and mistaken personal identity - it appears to go through the same process that Severina goes through in Ciampa's study (1987): She goes from being someone's slave to being a slave of herself. 


\section{REFERENCES}

BECKER, H. Outsiders. Rio de Janeiro: Zahar, 2008.

BRASIL. Diário do Senado Federal, ano LXX, n. 199, 9 de dezembro de 2015. Available at: <http://legis.senado.leg.br/diarios/Busca Diario?tipDiario=1\&datDiario=09/12/2015\&paginaDireta $=00043>$. Accessed on: July 22, 2016.

CAMPOS, A.; SOEIRO, J. A falácia do empreendedorismo. Lisboa: Bertrand, 2016.

CARVAlHO, B. P. A Escola de São Paulo de Psicologia Social: uma análise do seu desenvolvimento desde o materialismo histórico. 273 f. 2014. Thesis (Master in Social Psychology) - Programa de Mestrado em Psicologia Social, Pontificia Universidade Católica de São Paulo, São Paulo, 2014.

CASTRO, E. M. A.; LISBÃO, Y. M. Forma-personagem e fetichismo: uma leitura complementar à obra de Ciampa. Psicologia \& Sociedade, v. 29, e170759, 2017.

CHAUI, M. Cultura e democracia. São Paulo: Cortez, 2007.

CIAMPA, A. C. A estória do Severino e a história da Severina. São Paulo: Brasiliense, 1987.

CIAMPA, A. C. Entrevista. Constr. Psicopedag., São Paulo, v. 14, n. 11, Dec. 2006. Available at: <http://pepsic.bvsalud.org/scielo. php?script=sci_arttext\&pid=S1415-69542006000100002\&lng=es\& nrm=iso>. Accessed on: Nov. 09, 2016.

CIAMPA, A. C. Identidade humana como metamorfose: a questão da família e do trabalho e a crise de sentido no mundo moderno. Interações, v. 3, n. 6, p. 87-101, 1998.

CIAMPA, A. C. Identidade. In: LANE, S. T. M.; CODO, W. (Org.). Psicologia social: o homem em movimento. São Paulo: Brasiliense, 1994. p. 58-75.

CUNNINGHAM, J. B.; LISCHERON, J. Defining Entrepreneurship. Journal of Small Business Management, v. 29, n.1, p. 45-61, Jan. 1991.

DESCHAMPS, J.-C.; MOLINER, P. A identidade em psicologia social. Petrópolis: Vozes, 2009.

ELIAS, N. Escritos e ensaios. Estado, processo, opinião pública. Rio de Janeiro: Zahar, 2006. v. 1.

ELIAS, N. Introdução à sociologia. Lisboa: Ed. 70, 2008.

ELIAS, N. Mozart: a sociologia de um gênio. Rio de Janeiro: Zahar, 1995.

ELIAS, N. O processo civilizador. Uma história dos costumes. Rio de Janeiro: Jorge Zahar, 1994b. v. 1.

ELIAS, N. Os alemães: a luta pelo poder e a evolução do habitus nos séculos XIX e XX. Rio de Janeiro: Zahar, 1997.

ELIAS, N. The society of individuals. Oxford: Basil Blackwell, 1991.

ELIAS, N., SCOTSON, J. L. established and the outsiders. London: Sage, 1994a.

ÉSTHER, A. B. A universidade como universidade corporativa global? O caso da formação em Administração. GIGAPP: Estudios/Working Papers, n. 64. p. 162-178, 2017.
ÉSTHER, A. B. Qual universidade para qual sociedade? Holos, v. 32, n. 7, p. 351-365, 2016.

FILION, L. J. Empreendedorismo: empreendedorismo e proprietáriosgerentes de pequenas empresas. Revista de Administração, v. 34, n. 2, p. 5-28, 1999.

GOFFMANN, E. Estigma. Rio de Janeiro: LTC, 2008.

GUARESCHI, N. M. F. Políticas de identidade: novos enfoques e novos desafios para a psicologia social. Psicologia \& Sociedade, v. $12, \mathrm{n}$. 1-2, p. 110-124, 2000.

HABERMAS, J. Para a reconstrução do materialismo histórico. São Paulo: Brasiliense, 1983.

LANE, S. T. M. A psicologia social e uma nova concepção do homem para a psicologia. In: LANE, S. T. M.; CODO, W. (Org.). Psicologia social: o homem em movimento. São Paulo: Brasiliense, 1994. p. 10-19.

LANE, S. T. M.; CODO, W. (Org.). Psicologia social: o homem em movimento. São Paulo: Brasiliense, 1994.

LIMA, A. F. Metamorfose, anamorfose e reconhecimento perverso. São Paulo: Educ, 2010.

LIMA, A. F.; CIAMPA, A. C. Metamorfose humana em busca de emancipação: a identidade na perspectiva da psicologia social crítica. In: LIMA, A. F. (Org.). Psicologia social crítica: paralaxes do conhecimento. Porto Alegre: Sulina, 2012.

LIMA, A. F.; CIAMPA, A. C.; ALMEIDA, J. A. M. Psicologia social como psicologia política? A proposta de psicologia social crítica de Sílvia Lane. Psicologia Política, v. 9, n. 18, p. 223-236, 2009.

MUNIZ, M. A única explicação para estar desesperado com a crise. Administradores.com, João Pessoa, Feb. 24, 2016. Available at: $<$ https://administradores.com.br/artigos/a-unica-explicacao-paraestar-desesperado-com-a-crise>. Accessed on: June 02, 2017.

PAULA, A. P. P. Por uma nova gestão pública. Rio de Janeiro: Ed. FGV, 2005.

POKER, T. C. D. O que eu fiz com o que as instituições fizeram de mim? A história de Molly, e a sua luta por emancipação frente às políticas de identidade no acolhimento institucional. 237 f. 2014. Thesis (Master in Social Psychology) - Programa de Mestrado em Psicologia Social, Pontificia Universidade Católica de São Paulo, São Paulo, 2014.

SEN, A. Identity and violence: the illusion of destiny. London: Penguim, 2006.

SENNET, R. The corrosion of character: the personal consequences of work in the new capitalism. New York: W.W. Norton \& Company, 1998.

SENNETT, R. A cultura do novo capitalismo. Rio de Janeiro: Record, 2006.

SOUZA, R. F.; GONÇALVES, A. L. V. A mesmice identitária: a (im) possibilidade de emancipação na política de assistência social. Psicologia \& Sociedade, v. 29, e171276, 2017.

STANDING, G. The precariat: the new dangerous class. London: Bloomsbury, 2011.

STRAUSS, A. L. Mirrors and masks: The search for identity. The Sociology Press, 1969. 
VEIGA, C. G. Civilizar: tensões entre violência e pacificação nas relações de alunos e professores na institucionalização da escola pública elementar, Brasil, século XIX. In: GOETTERT, J. D.; SARAT, M. (Org.). Tempos e espaços civilizadores: diálogos com Norbert Elias. Dourados, MS: Ed. UFGD, 2009. p. 83-101.
VEIGA, C. G. Organização da nação e monopolização do ensino pelo estado: homogeneidade cultural e exclusão sociorracial (Brasil, séculos XIX e XX). Comunicações, v. 24, n. 3, p. 171-189, 2017.

Angelo Brigato Ésther

ORCID: https://orcid.org/0000-0001-9084-3746

PhD in Administration from the Graduate Center of Research in Administration (CEPEAD) at the Federal University of Minas Gerais (UFMG): PostDoctorate from the Center for 20th Century Interdisciplinary Studies from the University of Coimbra (CEIS20/UC); Leader of the Socius Research Group about University Institution; Associate Professor at the Federal University of Juiz de Fora (UFJF); Professor and Coordinator of the Academic Masters in Administration in the Faculty of Administration and Accounting Sciences. E-mail: angelo.esther@ufjf.edu.br 